Ovio Olaru

Faculty of Letters, Lucian Blaga University of Sibiu

Sibiu, Romania

ovio.olaru@ulbsibiu.ro

\title{
PRODUCING SOCIAL MOBILITY. CLASS AND TRAVEL IN THE ROMANIAN NOVEL 1901-1932
}

Recommended Citation: Olaru, Ovio. "Producing social mobility. Class and Travel in the Romanian Novel 1901-1932". Metacritic Journal for Comparative Studies and Theory, 6.2: https://doi.org/10.24193/mjcst.2020.10.08.

Abstract: The present article addresses the Romanian novelistic production between 1901 and 1932 in the attempt of identifying a series of patterns regarding the protagonists' social mobility. Starting with the most mentioned destinations throughout the novels, I analyse how and why the different social classes travel and try to determine the landmarks between which they dispute their physical presence, on the one hand, and their aspirations, on the other. On this basis, the second part of the article conducts a quantitative analysis of the major means of transport in the period - the train, the tramway, the coach/carriage, the automobile, the aeroplane, the ship, and the waggon - and attempts to pinpoint what they convey about the social mobility of the characters that use them.

Key words: Romanian novel, nineteenth century fiction, distant reading, quantitative analysis, class, travel

Since its very emergence, the novel has been assigned the sort of role which happens to coincide with the function of a healthy press and of a healthy civil society: to reflect the state of affairs, to take the pulse of contemporary life, and to ultimately give voice to much needed criticism in regard to what are perceived as aberrations in the public sphere. Indeed, as Galin Tihanov has argued, the novel is "the preeminent, if not the sole, embodiment of heteroglossia, the cultural form that is best suited to capture and accommodate the often-divergent languages and voices at work in society" (Tihanov 103). 
But what society? Or, better yet, whose society? Reading the novels of $19^{\text {th }}$ century Romania, one would get the impression that one is reading, for the most part, a combination of Alexandre Dumas and Eugène Sue (Baghiu et al., Geografia internă 32). Not because the novelists themselves are avid readers of these two, but because their aims fall short of "accommodating the often-divergent languages and voices at work in society": they are rather attempts at importing foreign genres without the slightest intention of adapting them to Romanian social realities. For instance, Terian et al. have demonstrated that, albeit the Romanian population of the second half of the $19^{\text {th }}$ century was overwhelmingly rural, even the rural novel subgenre seemed to borrow massively from a type of bucolic, idealized, atemporal rural discourse from abroad, brazenly misrepresenting Romanian social realities (Terian et al. 20).

In the present issue, Ștefan Baghiu and Cosmin Borza (Baghiu and Borza 107128) demonstrate that the lower classes, i.e., the workers and the peasants (in the lack of a proper industrial or agricultural modernization during $19^{\text {th }}$ century Romania, physical labour was the hallmark of peasantry; peasants were labourers, workers were not necessarily peasants), albeit being cast as protagonists in the novels, are never granted complete autonomy, in the sense that they never feature entirely as workers or peasants. Their essence is their work, an element which defines all aspects of their existence. Yet, their profession is always mitigated by the writers' unconscious bias or - for the most part - downright political agenda. They are either the bucolic embodiment of atemporal peasantry, the hungry, ignorant, obnoxious, and ultimately despised mob, or the convergence point of anticapitalistic feelings: perversely exploited, constantly deceived, and precarious.

In this case, because the society reflected by the Romanian novels does not belong to the lower classes, even if they make up the most consistent segment of the social body, we will not inquire as to whose society the authors are trying to depict since it is obvious -, but rather: how can the lower classes take this society into possession?

Throughout this article, I attempt to determine whether or not there is a correlation between social class and geographical mobility. More precisely, if and how can geographical mobility transform into social mobility? In doing so, I rely on the metadata supplied by the Digital Museum of the Romanian Novel: 1901-1932 (Muzeul Digital al Romanului Românesc, part II; the first one covered the Romanian 
novel of the $19^{\text {th }}$ century) project, whose archive, albeit not yet published, consists of approximately $80 \%$ of the period's novelistic output. When looking at the metadata gathered from the DMRN II archive, it seems that, whereas certain information such as the genre or the time in which the novels were set are more difficult to discern not least because certain novels stretch over longer periods of time and certain others do not specify time at all -, one thing can be determined with relative ease: the protagonist's social bearing, his class origin. Where do people from different social strata travel to and why?

In an article co-authored together with Ștefan Baghiu, Andrei Terian, Vlad Pojoga, Teodora Susarenco, and Iunis Minculete (Baghiu et al., Străinătatea 1-11), my particular contribution regarded the issue of travel. I will hereby try to resume some of the conclusions, referring to the period's three main social classes that have been indexed in the archive. My argument is that the cities where the novels take place and those that are mentioned without serving as background for the narrative are equally important. The former determine the present ${ }^{1}$ geographical mobility of the heroes, whereas the latter embody their aspirations. One can notice the Romanian obsession with the Western world - and implicitly also the Western aspiration - in the insistence with which Paris and other destinations from abroad are mentioned without once playing a role in the plot. As the articles' authors, including myself, remarked:

This is noticeable in several novels spread across the entire period, such as A Death that proves Nothing/O moarte care nu dovedește nimic (1931), by Anton Holban, Failing Romanian Class/Corigent la limba română (1928), by Ion Minulescu, Double Life/Viața dublă (1927), by E. Lovinescu, or Mechanical Ballet/Baletul mecanic (1931), by Cezar Petrescu, to name just a few of the most renowned. This latter novel is surprising through its unprecedented cosmopolitanism: not only does it take place in Nice and Monte Carlo, but it mentions, in this order, the cities of Grasses, Rio de Janeiro, Buenos-Aires, San Remo, Grenoble, Chicago, Valencia, Rome, Venice, Marseille, Barcelona, Bucharest, Constanța, Paris, Moscow, New York, Saint Petersburg, Berlin, and Vienna ${ }^{2}$.

\footnotetext{
${ }^{1}$ Present in the literal sense of the word: contemporary, since, as Vancu et al (22-32) noted, most of the novels of this period are set in contemporary times and speak about their own epoch.

2 Observăm acest lucru în numeroase romane răspândite de-a lungul întregii perioade, printre care $O$ moarte care nu dovedește nimic (1931), al lui Anton Holban, Corigent la limba română (1928), al lui Ion Minulescu, Viața dublă (1927) al lui E. Lovinescu sau Baletul mecanic (1931), romanul lui Cezar
} 
The upper classes and the bourgeoisie move freely between the country's main urban centres, but are also extraordinarily international in their mobility. However, is this mobility real?

For the characters belonging to the nobility (consisting of nobles, boyars, politicians, princes, and the likes), the places where the action preponderantly takes place are Bucharest, Paris, and Jassy, in this order. The most mentioned cities are Paris, Bucharest, Vienna, Berlin, Galați, Venice, and Brașov. Regardless of whether or not the narrative takes place in these cities, their mere mention is an indicator of the authors' Western aspirations; in this sense, mentioning Western-European capitals pursues the transformation of geographical mobility into cultural fluidity ${ }^{3}$.

What does this entail? First of all, the disparity between mentioning and visiting also betrays a Western aspiration: Paris is on everybody's lips, without necessarily being described in detail. Parisian streets are not the backdrop of narratives, but are rather hidden from sight, and make the object of conversation without being physically visited in the text. Paris, London, or Vienna are mentioned in the same manner in which famous historical figures are mentioned in "false" historical novels, whose actual plot is actually sentimental, sensationalist, or pertaining to crime fiction. The authors are constantly "namedropping" desirable destinations, in an attempt to overcome their perceived provincialism, Balkanism, and overall backwardness. But in order to name-drop, one must first be aware of the name, i.e., of what constitutes a desirable, fashionable destination, and one must also be aware of the increase in symbolic capital entailed by this name dropping among one's peers. That is why these characters belong to the bourgeoisie and to the aristocracy: they are the peripheral intelligentsia mediating the cultural commodities of the West within their own class: language, attire, habits, social customs, and the arts. They do not pursue

Petrescu (pentru a le numi doar pe câteva dintre cele mai cunoscute). Acest din urmă roman surprinde prin cosmopolitismul nemaivăzut: nu numai că acțiunea are loc la Nisa și Monte-Carlo, dar menționează, în această ordine, orașele Grasses, Rio de Janeiro, Buenos Aires, San Remo, Grenoble, Chicago, Valencia, Roma, Veneția, Marsilia, Barcelona, București, Constanța, Paris, Moscova, NewYork, St. Petersburg, Berlin și Viena. (5).

3 Pentru personajele din medii aristocrate (însumând nobili, boieri, miniștri, prinți), locurile predilecte de desfăşurare a acțiunii sunt București, Paris și Iași, în această ordine. Locurile cele mai menționate sunt Paris, București, Viena, Berlin, Galați, Veneția și Brașov. Referințele la capitale vesteuropene urmăresc aici să transforme mobilitatea geografică a protagoniștilor în fluiditate culturală. (5). 
social mobility, since they are relatively well-off, but rather the acknowledgement of their fluid identity. But who is left to acknowledge their greatness, considering that in 1938, six years after the conclusion of this period, Romania still had a $54 \%$ illiteracy rate (Dobre 131) and one of the lowest life expectancies in Europe? (Dobre 277)

This rhetorical question brings us to the third social class of early $20^{\text {th }}$ century Romania, simultaneously the ones least represented in the literary production (Baghiu and Borza): the peasantry. Its mobility is disputed

between the village, which is most often not even provided a proper name, and Romanian cities: Focşani, Galaţi, Bacău, Caransebeș, Sibiu, Hunedoara, Giurgiu, Brăila, but also cities located in the eastern European proximity: Belgrade, Bratislava, Budapest, Krakow. 4

The village is not given a name, as its existence is inscribed in the landscape, the attires, the objects which surround the characters, or in their language. The absence of a name signals either that it does not matter, since the narrative could have unfolded some other place just as well, therefore raising implicit claims on its universality, or it could mean, on the other hand, that the countryside as a whole is regarded as terra incognita, homogenous in its backwardness, precariousness, and so on, and usually negatively connoted. When it is named, however, the action is inextricably bound to the confines of the village, which closes the narrative within its borders: every "escape" from the village is somehow fateful, as in Ion Agârbiceanu's Arhanghelii (1914): "If he went to the city, he'd spend there a week, throwing his money away like grains of sand" (Agârbiceanu 100); "His sisters used to tell him with a sadness of sorts about the happiness of the notary's daughter in the big city. None of them spoke badly of her, but Vasile felt from their voices that they regret not having as much money as Elenuța” (Agârbiceanu 21). We encounter this sort of travel ban in Liviu Rebreanu's Ion as well, where only the elites travel (Pojoga et al. 33), while the peasants remain "inside" to resolve their conflicts. Other writers attempt to resolve the social struggle of peasant characters outside the rural space; in this case, to escape from the village life means to force the production of social mobility. When this escape is involuntary, we are usually dealing with war and its nefarious effects:

\footnotetext{
4 între sat, care cel mai adesea nu este numit ca atare, și oraşe autohtone, precum Focşani, Galați, Bacău, Caransebeş, Sibiu, Hunedoara, Giurgiu, Brăila ș.a.m.d., dar şi zone din vecinătatea esteuropeană: Belgrad, Bratislava, Budapesta, Cracovia (5).
} 
social mobility perhaps takes place, but only accidentally, and fundamentally as a result of decisions taken by the upper-class: politicians, monarchs, and the entire institutional mechanisms entrusting them with these decisions.

Throughout the Romanian novels of the early $20^{\text {th }}$ century, it was quite predictable that the wealthy - nobles and aristocrats, as well as high-ranking civil servants - and those that aspire to be wealthy - the bourgeois: doctors, lawyers, merchants - are more likely to travel to foreign destinations. It was also predictable that most of the exotic destinations mentioned throughout the novels are, in fact, nothing more than an attempt to appeal to the cosmopolitan aspirations of the period's readership. But most of these destinations are not necessarily "useful" for the narrative itself, they do not contribute to its evolution or fulfilment, but are merely - in the words of Baghiu and Borza - a sort of "aspirational decorum", providing enjoyment only inasmuch as they soothe the inferiority complexes of a provincial culture at the edge of "civilized" Europe.

\section{The airplane and the waggon. Transporting class}

Every type of production logically possesses a means of production. How do Romanian authors transform geographical mobility into social mobility? Mobility, both in the physical and in the symbolic sense of the word, requires means of transportation. Even if these infrastructural channels are not necessarily named, we have to take heed of the changes in transportation technology brought about during the early $20^{\text {th }}$ century and how these changes are reflected in the period's literature. We must assume that every radical shift in the dominant means of transportation will inevitably enjoy at least some mention, not necessarily because it would risk forever replacing the established means - the railway, the carriage -, but barely owing to its exotic, never-before-seen nature. For a peripheral country whose technological advancements have never been outstanding, but which nonetheless admires the advancements of the West, observing the change in infrastructure or the change in the way in which infrastructure is instrumentalized in literature will prove itself crucial for understanding how the characters relate to the world outside their symbolic and literal "enclosures".

To this end, the quantitative analysis will pursue a semantic search in the DMRN II archive, representing approximately 80\% of the period's novelistic output, after a series of terms or lexical clusters relating to common or emerging means of 
transportation. The focus will fall primarily on the emerging automotive imaginary with its 'automobil'/automobile' - and on horse-drawn vehicles - with its two very differently connoted terms, 'căruță' ('cart' or 'waggon') and 'trăsură' ('carriage' or 'coach'), but also on the railway system - most recognizable through its train, 'tren', on maritime travel - represented through 'vapor's -, and on the newest invention in terms of travel, the aeroplane - whose illustration is the aeroplane/ 'aeroplan'. Although am I interested in the entire array of possible infrastructural facilities of the early $20^{\text {th }}$ century, I limited my search to a set of illustrative terms for each mode of transportation. The reason for this is that the "main" term, as it were, will usually follow the set of possible auxiliary terms from the same semantic field. In other words, the latter will converge towards the former. Searching for both the main term, as well as for the auxiliary ones will yield artificially enhanced results. Therefore, I have eluded words such as 'personal', 'accelerat', 'cale ferată', 'locomotivă', 'vagon', 'șine', and so on, since perhaps not all of them, but an overwhelming majority will gravitate around 'tren'. In much the same way, the preferred term for 'car' in the early $20^{\text {th }}$ century is 'automobil'; its ancillary terms: 'șofer', 'volan', 'claxon', and so on will most likely not be mentioned without it. Similarly, 'aeroplan' is still preferred over the French 'avion' or over 'aeronavă'; in this manner, I am sure to exclude mentions which could refer to our means of transportation, but do not necessarily do so.

However, in regard to horse-drawn vehicles, I have decided to make a distinction. Without searching for auxiliary terms such as 'birjă', 'surugiu', 'capră', 'vizitiu', 'hamuri', 'cal', 'înhămat', and so on, I did conduct two searches. The first one regards the horse-drawn, preponderantly urban carriages ('trăsură'), the other is the much more versatile - in the sense of carrying goods and passengers alike -, but considerably less comfortable, cart/waggon ('căruță'), the staple of every rural household.

Let us address all these terms in the order of their relevance. The first one is vapor, meaning ship; it has 305 mentions spread across 104 documents. The ship evokes images of foreign, mysterious, and dangerous destinations: it is associated with romanticised notions of travel - inevitably bound to the upper-class -, as well

\footnotetext{
5 Initially, I had thought to broaden the search to include valid alternatives designating this type of transport, such as 'corabie', 'navă, or 'ambarcațiune', as well as possible auxiliary terms, but the endresults for all of these searches were insignificant except for 'vapor'. The disappointingly few results are, to a certain extent, also understandable: Romanian literature lacks a proper naval imagery.
} 
as being the only instrument for transatlantic travel of that time - again, a marker of the upper-class. Albeit interesting, it is by no means as relevant as newer forms of transportation: the aeroplane appears a number of 50 times throughout 28 works. It is unsurprisingly a machine whose introduction is still so outlandish that it is first mentioned in two science fiction novels, H. Stahl's Un român în lună (1914) and Victor Anestin's O tragedie cerească. Poveste astronomică (1914). In overwhelming majority, its presence is noted in relation to World War One, as instrument of a cold, impersonal annihilation, part of the "war of machines" (Rolando 137) or part of terror attacks directed against the civilian population (such as in Dem. Theodorescu's In cetatea idealului, published in 1920). If we attempt to outline its social and cultural function, its most suggestive description is in George Cair's Nevroză: "It was the first time that one could see an aeroplane flying in our city, and massive crowds had gathered at the Hippodrome, fully covering the tracks and the surrounding areas. All the people had come from the city to see this. Aunty Melanie could not miss this for the world. The night before, she had prepared her most beautiful dress, together with the most sumptuous jewellery from her good old days. 'Like in Paris, like in Paris!" (Cair 226-27). When not regarded as a miraculous piece of engineering, the aeroplane is a pretext for unprecedented travels and adventure, as in Alice Gabrielescu's Uimitoarele întâmplări dintr-o vacanță. Roman pentru copii şi tineret (1927), or, not unlike a fine horse or an automobile, an object of recreation and a status symbol: "Popică (dandy, his hair powdered): I swear on my mother, I swear on my life, I swear on my aeroplane!" (Holban 135). Even when maintaining their life-threatening potential, aeroplanes still exude, for the upper-class protagonists, the harmless appeal of a past-time activity: "On the sky, the aeroplanes were flying in jest, giving the impression they were made for fun rather than for battle, and when one of the foreign aeroplanes rarely passed over the city, it dropped no bomb which could scare us" (Holban 315). As regards the train, it features a total of 1123 times throughout 235 novels, many of them concentrated towards the end of the period, 1931 to 1932 . CFR (The Romanian Railway) was founded in 1880 and the first proper passenger railway line had existed since 1857, but it was not until 1918, as the railway network of Transylvania, which had been obtained from the dissolving Austro-Hungarian Monarchy, was nationalized, that we can talk about a genuine national railway line. Perhaps this explains why the train is, on the one hand, ubiquitous, but, unlike the aeroplane, unremarkable in its use. It designates travel for 
whatever purpose, but does not make the object of awe and does not inspire further commentaries. It is merely an instrument - albeit a still perfectible one ("it was the horrendous moment of boarding the train. Will he find a seat? And, if he will, won't a lady kindly ask him to let her have it? Won't he end up - God forbid! - in a compartment with a large family, with screaming children? [...] Between him and his great happiness - three days in Bacău! - were so many barriers...” - TeodorescuBranişte 33). The emergent form of transportation to replace the train is the tramway (443 occurrences in 138 novels), the use of which is regarded as shameful and embarrassing, since it often transports the working class from the slums to the city centre: "They had decided that Aimée was to come the next day to pick up the girls in his automobile. Minette had displayed a naïve joy; it was an embarrassing detail of their lives that they often had to take the tramway while donning formal attire" (Papadat-Bengescu 64).

I will now address the three most "ideologized" means of transportation in the Romanian novels of the early $20^{\text {th }}$ century. The automobile, the carriage, and the waggon. The automobile is featured a total of 735 times throughout 153 works (being mentioned an average of 4,8 times per work). In most situations, it is driven by an employed driver, not by the owner. It therefore requires a new type of servant with a different degree of specialization, who can drive the machine, but also repair it in case it breaks down unexpectedly. This specialized servant is already in many respects different from the habitual understanding of the servant performing manual labour for his boyar: his position demands part of the respect directed to the automobile's owner, but also illustrates the shift from the vizitiu/coachman (with 713 occurrences in 169 works or an average of 4,2 occurrences in each work) to the employed driver (274 occurrences throughout 73 works or an average of 3,75 mentions per work), a shift that clearly signals a mutation of labour: whereas the coachman was oftentimes part of the narrative and engaged in conversation with the passengers/other protagonists, the driver is an employed professional; the unusually high frequency with which he is mentioned, considering that he does not participate as much in the narrative, owes to the author emphasizing his presence, utility, and function in the service of the upper-class hero. Much like 'Paris', 'driver' is a form of namedropping: the driver is unimportant for the plot, but highly ornamental.

Therefore, the automobile is a status symbol ("In front of us was an automobile. On its plush seats sat a dignified gentleman. He must hold some 
executive office in one of the Ministries" - Holban 361) and betrays close social and financial ties with the Western world ("Albeit there was only two of them, they had a large house, with all the modern facilities: radiator, electricity, landline, automobile. On Wednesday, the entire high-life displayed their garments and hats brought from Paris or London" - Xenopol 20; "journalists assured him that he was a wealthy American who will one day come driving an automobile, his pockets full of dollar bills" - Sadoveanu 234). At first, automobiles are equated with ostentatious wealth, but later on, they are shown as being capable of actively modernizing the provincial Romanian streets with their bare speed, innovation, and - for that time - futuristic design: "We're lucky to have become civilized - she gleefully answered ... Nowadays, we can renounce your buggy and your whip, celebrating our wedding in the automobile ... 60 kilometres an hour! ... the ecstasy of speed aroused the newlywed, modernizing them ..." (Moldovanu 32).

After the initial bewilderment fades away (“An automobile? I'm scared, it's really new up here, we haven't seen as many of these things; can you drive?" - Smara 22), automobiles end up taking part in the city life, their presence falls among the natural urban landscape ("Automobiles came hurriedly, puffin. Officers threw themselves on the seats and off they were" - Sadoveanu 47) and soundscape ("Birds' chirping, the youngsters loudly laughing, the sound of hurrying coaches, and the now and then siren of an automobile converged in a symphony whose partiture could be perfectly discerned by Zoe's soul, who had lived in Bucharest her entire life" Samarineanu 155). Ultimately, unlike the train or the tramway, the automobile is individualistic instead of collective. The train is mentioned considerably more, but mainly as background: unlike the train, the automobile can be fetishized as private property, a marker of upper-class protagonists.

Next in line is the coach/trăsura. It occurs a total of 3.107 times throughout 298 novels and is mentioned 10,4 times per book, on average. Unlike the automobile, its presence is unremarkable. It is not fetishized as technological feat, nor as private property. However, it is still a class marker, since it is largely employed within the city, by the nobles and the bourgeois, and not by peasants, who still use the waggon/căruța. The waggon is mentioned a total of 965 times throughout 189 works (an average of 5,1 mentions per work). In most of the works, the waggon reinforces a mostly rural imagery: it appears naturally and does not make the object of careful inspection or metacommentary. It is not seen as the marker of rural life the way the 
automobile was seen as the very embodiment of urban life, but rather as a tool: helping useful people do useful things ("he carried in his waggon a dying child to Costești so that the doctor may see him” - Rebreanu 173). When it is described, its description refers to something else entirely: it usually helps determine the narrative atmosphere, it reinforces preconceptions about rural backwardness ("a waggon creaking hard and dry from every bolt” - Agârbiceanu 203), or helps convey the hardships of war ("in a waggon moaning under the weight of five or six corpses" Dragu 25).

In the end, we must ask ourselves the question: which one of these means of transportation succeeds in transforming geographical mobility into social mobility? Unsurprisingly, none of them can guarantee climbing the social ladder, but each of them has a status and occupies a place in the travel imagery. The automobile has the advantage of speed, of distance, and the freedom to choose one's own trajectory. As I have shown, however, it does not produce social mobility, but only shows its acquirement post factum. The tramway coexists, within the urban space, with the coach. Whereas the latter is rendered invisible by the deafening horns of the automobile, the tramway - together with its weightier counterpart, the train - is held in contempt for being too proletarian, the coach still entails some degree of social capital - though not so much as being in possession of a private automobile -, since it makes use of an employed or contracted servant, and does not force the protagonist to mingle with his fellow citizens or rely on the schedules of public transportation. Lastly, the waggon is mostly used for utilitarian purposes: the lighter, simpler version of the coach, it escapes description because it is ubiquitous, even if it performs the most basic and crucial tasks in the rural world. Whereas urban means of transportation serve the sole purpose of transporting people to and fro, the waggon carries people, animals, and goods alike. Even if it is the peasantry's only connection to the outside world, it alone cannot produce social mobility.

\section{References}

Agârbiceanu, Ion. Arhanghelii. Luceafărul, 1914.

Baghiu, Ștefan et al. "Geografia romanului românesc (1901-1932): străinătatea." The Geography of the Romanian Novel (1901-1932): Spaces from Abroad]. Transilvania, no. 10, 2020: 1-11. 
Baghiu, Ștefan, and Cosmin Borza. "The Sickle and the Piano. A Distant Reading of Work in the 19th Century Romanian Novel". Metacritic Journal for Comparative Studies and Theory, 6.2, 2020: 107-128: https://doi.org/10.24193/mjcst.2020.10.06.

Baghiu, Ştefan et al. "Geografia internă a romanului românesc în secolul al XIXlea”. Revista Transilvania no. 10, 2019: 29-43.

Cair, George. Nevroză. Tip. „Națională”, 1924.

Dobre, Gheorghe. Economia României în context European - 1938. Editura Fundației Științifice “Memoria Economica”, 1996.

Dragu, Ioan. Moartea Albă. Campania anilor 1916-1918. I. Brănișteanu, 1918.

Holban, Anton. Parada dascălilor. Editura de Stat pentru Literatură și Artă, 1932.

Moldovanu, Corneliu. Purgatoriul. Cartea Românească, 1922.

Papadat-Bengescu, Horotensia. Drumul ascuns. Editura Naţională S. Ciornei, 1932.

Pojoga et al. “The Character Network in Liviu Rebreanu's Ion: A Quantitative Analysis of Dialogue". Metacritic Journal for Comparative Studies and Theory, 6.2, 2020: 23-47: https://doi.org/10.24193/mjcst.2020.10.02.

Rebreanu, Liviu. Răscoala. Editura „Adeverul”, 1932.

Rolando, Sylvius [Victor Papilian]. Ne leagă pământul. Editura Literară a Casei Şcoalelor, 1926.

Sadoveanu, Mihail. Strada Lăpuşneanu. Cronică din 1917. Viața Românească, 1921.

Samarineanu, M. G. Romanță fără note. Oradea, 1932.

Smara. Fata tatii. Roman de moravuri. Tip. M.M. Antonescu, 1912.

Teodorescu-Braniște, Tudor. Domnul Negoiță. Sau individul împotriva statului. Editura Națională S. Ciornei, 1932.

Terian, Andrei et al. "Genurile romanului românesc în secolul al XIX-lea. O analiză cantitativă”. Revista Transilvania, no. 10, 2019: 17-28.

Tihanov, Galin. The Birth and Death of Literary Theory: Regimes of Relevance in Russia and Beyond. Stanford University Press, 2019.

Vancu, Radu et al. "Temporalitatea internă a romanului românesc (18441932)”. Revista Transilvania, no. 10, 2020: 22-32.

Xenopol, Adela. Pe urma războiului. 1913. 